\title{
EDITORIAL
}

\section{Thank you Peter and Paul}

\author{
J.C. Yernault
}

On 18 March 1982, the Societas Europeae Physiologiae Clinicae Respiratoriae (SEPCR) Executive Committee agreed that the Society should have a journal with mandatory subscription for its members in the Western European countries. Negotiations started with Paul Sadoul, the founder and Editor in Chief of the Bulletin Européen de Physiopathologie Respiratoire, which at that time was published by Pergamon Press. An ad hoc working party, chaired by Peter Howard, was mandated to enquire into the nature of the arrangements with the publishers. After considerable negotiations, P. Sadoul succeeded in buying back the Journal from Pergamon and offered it to SEPCR.

In 1983, the Bulletin became the official SEPCR journal, Peter Howard remaining chairman of the Management Committee, which was created to interact with Bialec, the printing company, and J. Clarendon, the technical editor, both based in Nancy. With a circulation of about 1,300 copies, the budget was difficult to equilibrate and some technical activities were progressively transferred to the Management Office in Sheffield.

Meanwhile, at the scientific editorship level, contacts were being established between the Bulletin and the European Journal of Respiratory Diseases (EJRD). The latter journal resulted from the merger in the late 1970s between the Scandinavian Journal of Respiratory Diseases, whose Editor was Erik Berglund, and Acta Tuberculosea et Pneumologica Belgica, whose Editor was Paul Vermeire. Good prospects for co-operation were announced at the SEPCR General Assembly held in The Hague on 27 June 1985. Both Peter Howard and Paul Vermeire were actively involved in the first discussions about a merger between EJRD and the Bulletin, which took place with Munksgaard, the EJRD owner, and participated at the first official meeting held on 6 December 1985 in Copenhagen. Further discussions about contracts were led for the SEPCR side by Peter Howard and Philip Quanjer, at that time the Society's President. Negotiations ended in the signing of the first SEPCR-Munksgaard contract, which took place in Amsterdam in April 1987.

This contract included two of Peter Howard's leitmotivs, that he had precisely expressed in a report dated 11 February 1986: 1. "... it will soon be possible to use a microcomputer to put the scientific papers on a floppy disc, which can be inserted into the back of a printing machine to produce perfect print..."; and 2. "... in case of any merger, SEPCR should maintain its independence as a publisher...".
The European Respiratory Journal, officially born in 1988, was produced in toto with new technologies in Sheffield, with Peter Howard officially appointed Managing Editor, on behalf of SEPCR. For this specific purpose, Peter and his wife created a partnership company called Fulwood Scientific Text (FST) that was based in their private house called The White House.

Once the European Respiratory Society (ERS) was founded in 1990 after the SEPCR-SEP Meeting held in London, negotiations started between Peter Howard and the ERS, which ended in the transfer of all the FST assets to a company called ERS Journals Ltd, which was now fully owned by ERS, Peter Howard remaining Managing Director. Meanwhile, the Sheffield activities had enlarged to a point at which they had to be transferred to specific offices in the Hutton's Suite.

However, with his managerial capacities, Peter had pushed to establish additional activities, independently of the agreement with Munksgaard, successively the European Respiratory Review, the European Respiratory Topic, the Buyer's Guide and, most recently, the first European Respiratory Monograph. After 14 years of highly active involvement in SEPCR and ERS affairs and after retiring from Sheffield University, where he served as a Consultant in Respiratory Medicine, Peter decided to resign from any active position in the management of the Society. He deserves the gratitude of the European pneumological community for his achievements in the field of scientific publishing.

Paul Vermeire, another prominent figure, is now retiring as Chief Editor. Professor of Respiratory Medicine at the University of Antwerp (B) since 1973, Paul has served the European Journals since 1979, having been successively Section Editor of the EJRD from 1979 to 1987, Associate Editor of the ERJ in 1988 and 1989, and Editor in Chief from 1990 to 1995, remaining associated with Ulrich Costabel until recently. Under his editorship, the Journal has grown considerably both in terms of volume and of scientific quality, as testified by its significant and steadily increasing impact factor. His achievements are, however, not limited to his editorship skills. Paul was SEPCR Secretary General between 1984 and 1988 , and in this capacity he was a very active member of the SEPCR-SEP Working Party in charge of preparing the future merger.

Peter and Paul are to be heartily congratulated and thanked for their contribution to the building of the European temple for Respiratory Medicine. 